\title{
BUSINESS MODEL BASED IN A SUSTAINABLE INVESTMENT FUND
}

Adilson Canovas de Almeidaa, Dra. Lilian Lefol Nani Guarieirob, Dr. Aloisio Santos Nascimento Filhob

aSENAI CIMATEC, Brasil,

bProfessional Master's Degree in Sustainable Development, SENAI CIMATEC

\begin{abstract}
The intention of this article is to describe a business model based on a sustainable investment fund as an alternative to strengthen the national automobile industry. However, above all a model that could be functional for any company that is interested in strengthening its investment channels for research and development of first-hand products. Furthermore, a model that reduces investment reliance on its headquarters, consequently reducing the necessity of usage of the company's capital reserves. This work was carried out through a systematic review of the literature using the global internet network and based on research on scientific websites. The research showed that there is a similar model called the Equity Investment Fund (FIP). However, the FIP does not have a predefined commitment to any specific segment of the automotive industry.
\end{abstract}

Keywords: investment fund; sustainability; financial support; employability; profit

\section{MODELO DE NEGÓCIO BASEADO EM FUNDO DE INVESTIMENTO SUSTENTÁVEL}

Resumo. O objetivo deste artigo é descrever um de modelo de negócio baseado em fundo de investimento sustentável como alternativa para fortalecer a indústria automobilística Nacional, mas sobretudo um modelo que pode ser aplicado por qualquer empresa que tenha interesse em e fortalecer seus canais de investimentos para pesquisa e desenvolvimento de novos produtos, além de reduzir a dependência de sua matriz para investir em projetos regionais consequentemente reduzir a necessidade de utilização das reservas de capital da companhia. Este trabalho foi realizado através de revisão sistemática da literatura utilizando a rede global de internet balizada por pesquisa em sites científicos. Essa pesquisa mostrou que existe um modelo similar chamado de Fundo de Investimento em Participações (FIP), porém os FIP's não possuem compromisso pré-definido com algum segmento da indústria automotiva especificamente.

Palavras-chave: fundo de investimento; sustentabilidade; suporte financeiro; empregabilidade; lucro 


\section{INTRODUCTION}

In a complex economy as the contemporary one, investment funds could establish sequences of benefits to companies that work with intensive production. According to Securities and Exchange Commission (CVM, Instr.No.555 pg.8, chapter III, section 1, art.3) "investment fund is a collective investment modality, a pool of resources constituted by a condominium form, intentional investment in financial assets [1]."

Luiz Roberto Calado [2] and Associação Brasileira das Entidades dos Mercados Financeiro e de Capitais (ANBIMA) CPA-10 page 5 [3], say that "the investment funds are legally considered as condominiums of a special nature, "pool of resources", which will be created with the objective of pro rely mooting the collective resources application of its participants.

The investment funds could be the most democratic and inclusive system of providing investments access to everyone. There are some complex and sophisticated markets where the small investor does not have enough knowledge or capital to apply. As it happens in automotive sector, one could identify employees with all levels of education working for massive production. At Ford Brasil, for instance, there are approximately 8,000 direct employees and the majority of them does not make any sort of investments. One Investment Fund may open the opportunity for everyone who requires to provide a financial support to the company they belong to in exchange for profit and reinforcement of their own employability.

Indeed the awareness of connecting investment funds to the automotive industry supports the strength of the employees chain since they would not merely produce cars, but likewise they became part of the company. A giant volume of capital in the world is currently applied in investment funds.

There are roughly 70,000 funds worldwide establishing a net value of US $\$ 25.6$ trillion equivalent to almost ten times Brazil's Gross Domestic Product (GDP). There are more than 8,000 funds in Brazil that represent a net value of $R \$ 1.7$ trillion reais, where 2,000 of them could be elevated and that ranks Brazil within the fifth largest fund industries in the world. EID JUNIOR 2012 [4]. Only in 2019 Brazil funds and investment industry grew up 226\%. EXAME magazine [5].

Once the fund investment may be applied in some determined ways of interest, why wouldn't large companies be interested in being part of those investment funds? In that context, the Item 8 of the United Nations Sustainable Objectives [6], brings the need to promote economic, sustainable, inclusive growth, decent work and full employment for all. Thus, the proposal of this article was to present an investment fund model where companies with intensive production may strengthen their investment channels.

The automotive industry in Brazil does not have a significant national brand in the sector. Therefore, every auto industry in that country requires endorsement from its foreign headquarters to make innovative investments in projects of the region interest. This reliance to the national automobile industry is even more intensified in times of major economic crises, as in those periods there is a predisposition for hesitation on making new investments when it comes to development of first-hand products.

\section{METHODOLOGY}


Exploratory research on scientific websites was used as a method of survey, as it seeks to offer an overview of the subject leading to a better understanding of it. Exploratory research consists of collecting data and information on a given theme that one may acquire preliminary comprehensions. For this article, it was established to work with studies from governmental, private and public agencies recognized in the investment fund segment, as well as scientific studies on investments and business model. Subsequently, the data were analyzed and compiled to create an overview of the topic.

Just like the FIP model [2,5,7], we proposed a prospect of adding another investment channel for companies, reducing the dependence on their headquarters and relieving their main source of funds.

To better explain the model proposal using a visual method, the concept map tool was adopted applying the concepts of LA TORRE's [8] business model and Investment Fund by Roberto Calado [2].

A conceptual map proposal was elaborated by the author of this article (Figure 1), aiming to promote a comprehensive assessment of the suggested model for an automotive industry as an illustration, as well as to foment an understand of its interfaces, methods and processes.

\section{RESULTS AND DISCUSSION}

The result of the research revealed that a corporate investment fund could be an approach to diversify the business and to design a new sort of service to add value to the company and to the employee chain. Although the Equity Investment Fund (FIP) has already exists, there is no guarantee that the fund holder will invest his fund share neither at the specific company nor at the specific automotive industry [7]. Therefore, it would be indispensable to generate an FIP analogous fund with particular regulations regarding to applications focused on the achievement of the company projected objectives.

In accordance to the right side of the conceptual map in the figure 1, it is possible to visualize a currently structured business model in a simplified way and the company environment along with their headquarters and investments.

On the left side of figure 1 , however, it is possible to visualize a simplified manner on how an investment fund can add value to the product by creating a value chain, contributing to the automotive industry, employability to these employees and the sustainability of the method.

Additional tests should be required, and the model could still be improved, although the proposal resembles FIP model and will requires approval from CVM [2] and ANBIMA [5]. 


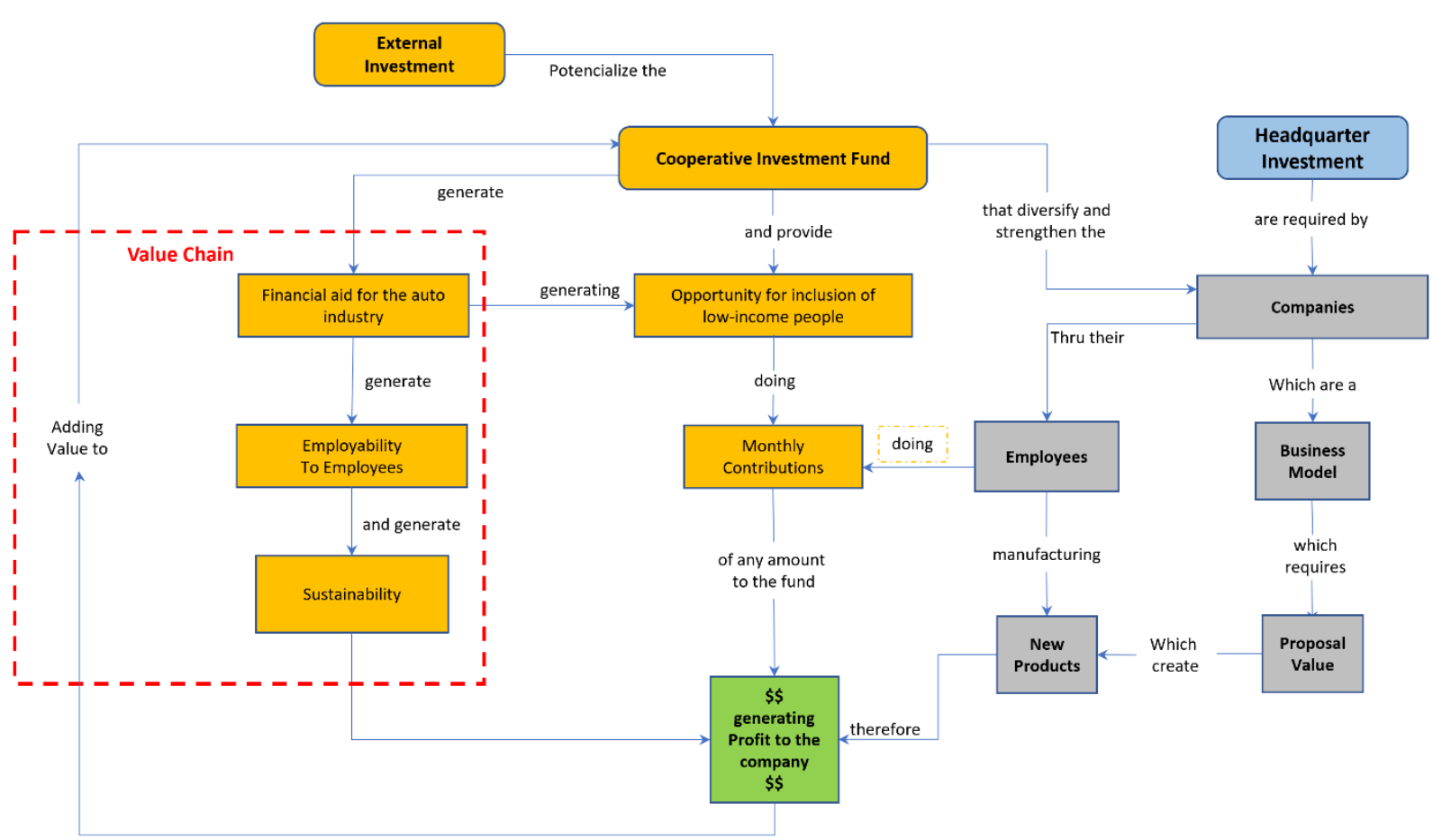

The conceptual map model above suggests that the sustainability of the method would be fed by the pool of investments created by their own employees and potential outside investors. The proposed model designs a possibility of increasing the product sales, assuming that the fund success relies on an investor interest, and generate the opportunity of investors themselves behave as sellers of the product, thus creating a value chain.

Since the model was never tested, it is not possible to confirm the results expected, although it is possible to understand the flow of activities and some premises like "inclusion". Employees and outside individuals may have the opportunity to have some participations shares of that fund, may receive payback from this investment and reinforce the company investments and their own employability.

Inclusion, sustainability, honest work, promote economic and full employment for all, as it is stated by the United Nations objectives [6].

Besides having a value proposition, a business model is able to solve a problem and even strengthening a social cause, in addition to promote the insertion in a sustainable and profitable environment. Actually, financial systems do not currently seem to fully adopt sustainability models and are unable to support the achievement of sustainable development goals [8]. everyone.

Therefore, opportunities and inclusive ways of investment must be provided for

\section{CONCLUSION}


Now-a-days, all companies have been looking for alternative methods of profit, and many of than have been deliberated about diversification. Some automotive industries are choosing the "service model" as a new way to improve their profits and keep growing.

Based on the model presented in this article, there is a possibility of multilateral gains for all stakeholders. Some other opportunities have also been foreseen depending on the rules and taxation package, in addition to adding value to the product and strengthening the company's financial structure.

Although there are risks inherent to this type of investment, there is also a very large scalable opportunity, once the portfolio is opened to outside investors, in addition to the potential to maximize the number of vehicles sold by the company due to the interest in the growth of the fund by the investor.

It is at the company discretion whether to use the fund or not, but to implement the investment fund only as an employee benefit. Obviously, rules need to be created to protect the company and investors. But such rules can be easily created following the existing economic models as well as the laws of the current financial market available. In order to implement these rules, it would be necessary to form a group of people with differentiated specific qualifications such as a tax attorney, an accountant, and a financial market inspector. Although it is possible to implement such fund with a low initial investment, supporting the objectives of all stakeholders providing some profit, inclusive investment, employability and a new channel of investment to the companies.

\section{REFERENCES}

${ }^{1}$ COMISSÃO DE VALORES MOBILIARIOS. Cotas de Fundos de Investimentos (409). 2013. Disponível em:

<http://www.portaldoinvestidor.gov.br/menu/Menu_Investidor/valores_mobiliarios/Fun dodel nvestimento409.html>. Acesso em 10/01/2020.

${ }^{2}$ Calado, Luiz Roberto Fundos de Investimento: conheça antes de investir / Luiz Calado. - Rio de Janeiro: Elsevier, 2011

3INVESTIR, COMO; DA ANBIMA, Portal da Educação Financeira. Associação

Brasileira das Entidades dos Mercados Financeiro e de Capitais. 2016.

${ }^{4}$ EID JUNIOR, William. Longo prazo, Poupança das Famílias e os Fundos de Investimento. 2012. Disponível em:

<http://cef.fgv.br/sites/cef.fgv.br/files/file/Estudo\%20V.pdf>. Acesso em: 10/01/2020

${ }^{5}$ REVISTA EXAME, Ângela Pavini.2019. Crescimento dos fundos de

Investimento. Disponível em: https://exame.com/mercados/fundos-de-

investimentos-captam-um-volume-226-maior-em-2019/.Acesso em 26/06/2020. 
${ }^{6}$ Nações Unidas, Objetivos de Desenvolvimento Sustentável.

https://odsbrasil.gov.br/ Acesso em 20/Jul/2020.

${ }^{7}$ DOS SANTOS, Estela Sucasas. Fundo de investimento em participações-FIP como instrumento de estímulo à inovação. 2019.

${ }^{8}$ LA TORRE, Mario et al. Business models for sustainable finance: The case study of social impact bonds. Sustainability, v. 11, n. 7, p. 1887, 2019.

${ }^{9}$ Torre, M. L., Trotta, A., Chiappini, H., \& Rizzello, A. (2019). Business models for sustainable finance: The case study of social impact bonds. Sustainability, 11(7) doi:http://dx.doi.org/10.3390/su11071887 